\title{
Diversity, abundance and pollination efficiency of insect pollinators of fennel (Foeniculum vulgare Miller) and effect of abiotic factors on insect pollinator activity
}

\author{
Vikas Bharti $^{*}$, Dilbag Singh Ahlawat ${ }^{2}$, Surender Kumar Sharma ${ }^{1}$, Naveen Vikram Singh ${ }^{1}$, \\ Jitender ${ }^{1}$ and Nachhatar Singh ${ }^{1}$ \\ ${ }^{1}$ Department of Entomology, CCS Haryana Agricultural University, Hisar-125 004, (Haryana), INDIA \\ ${ }^{2}$ Krishi Vigyan Kendra, Karnal-132001, Haryana, INDIA \\ *Corresponding author. E-mail: lav.bharti@gmail.com
}

Received: February 3, 2015; Revised received: July 20, 2015; Accepted: October 3, 2015

\begin{abstract}
Biodiversity of insect pollinators on fennel cv. HF-143 (Foeniculum vulgare Miller), was studied in Hisar, Haryana, India. Twenty-five insect species belonging to fifteen families of five orders were recorded from fennel flowers, in which, seven belong to order Lepidoptera, nine to Hymenoptera, five to Diptera, three to Coleoptera and one to Odonata. Among the insect pollinators, Apis florea F., A. cerana indica F., A. mellifera L. and $A$. dorsata $\mathrm{F}$. were the most frequent visitors. Among different bee species, the maximum mean population observed in case of $A$. florea $\left(9.23 \mathrm{bees} / \mathrm{m}^{2} / 5 \mathrm{~min}\right)$ followed by $A$. mellifera (3.62 bees $/ \mathrm{m}^{2} / 5 \mathrm{~min}$ ) and $A$. dorsata $\left(3.21\right.$ bees $/ \mathrm{m}^{2} / 5 \mathrm{~min}$ ), whereas, the least abundance was observed in case of $A$. cerana indica, i.e., 1.82 bees $/ \mathrm{m}^{2} / 5 \mathrm{~min}$. The pollination index of $A$. dorsata was highest (19715210) followed by A. florea (13888381), A. mellifera (13845052) and $A$. cerana (5586381). Hence, it was observed that $A$. dorsata was the most efficient pollinator followed by $A$. florea, $A$. mellifera and $A$. cerana on fennel cv. HF-143 flowers under agro ecological conditions of Hisar (Haryana). Hence, insect pollinators were essential to get good returns in this seed crop. The activity of different bee species on fennel varied with different abiotic factors and had significantly positive correlation with bright sun shine hours (BSS) and temperature (TEMP) in different hours of the day during foraging but had negative correlation with relative humidity $(\mathrm{RH})$. It was observed that the effect of wind velocity on foraging of different bee species was not significant. Thus, the impact of abiotic environmental factors may decide the foraging activity of different insect pollinators.
\end{abstract}

Keywords: Abundance, Abiotic factors, Foraging speed, Foraging rate, Fennel cv. HF-143, Pollination index

\section{INTRODUCTION}

Fennel (Foeniculum vulgare Miller), commonly known as saunf, is one of the most important winter season seed spices, grown in northern India. It grows well under dry and cold weather conditions, and therefore, it is cultivated in Gujarat, Rajasthan, Uttar Pradesh, Madhya Pradesh, Karnataka, Haryana and Punjab. In India and neighbouring countries, it is used as masticatory or for chewing alone or in paans. It is also used in cough, flatulence, colic, thirst and for flavouring soups, meat dishes, sauces, bread rolls, pastries, confectionary, liquors and in making pickles (Pruthi, 1976). Seeds are being used in medicines as a carminative, stimulant, stomachic and as a cure for earaches, toothaches, coughs, asthma and rheumatism. Pollination is one of the limiting factors for crop productivity and is significantly contributing to the agricultural productivity. Pollination, which is essential for the process of fertilization and production of fruits and/ or seeds, is defined as the transfer of pollens from male to female portion of a flower. In nature, only about 5 per cent of the flowers are self-pollinated and 95 per cent animal pollinated (Tewari and Singh, 1983) out of which 90 per cent accounts Insect pollination (Richards, 1986; Buchmann and Nabhan, 1996).

Since very meagre information is available on the insect pollination requirements of fennel, therefore the present study was carried out on the diversity, abundance of insect visitors/ pollinators, effect of abiotic factors on foraging activity of major insect pollinators and evaluataion of their pollination efficiency on fennel, Foeniculum vulgare Miller, in Hisar (Haryana), India.

\section{MATERIALS AND METHODS}

Study sites and climate: The experiment comprises fennel cv. HF-143 crop with two modes of pollination viz., open-pollination (OP) and without insect pollination (WIP) was conducted at Research Farm of the Department of Vegetable Science, CCS Haryana Agricultural University, Hisar (India). The experimental site is situated at $29^{\circ}-10^{\prime}$ North latitude and $75^{\circ}-46^{\prime}$ East longitude at an altitude of 215.2 meter above mean sea level. The climate of Hisar region is semi-arid and is characterized by hot and dry winds during summer months and dry and severe cold conditions during 
winter months. The maximum and minimum temperature showed wide range of fluctuations during summer, while the temperature below freezing point accompanied by frost was also be recorded during winter months (December-January), which is very common feature of this region. The rainfall was confined mainly to the monsoon months from July to September but light showers cyclonic rains also occurred sometimes during winter and spring months.

Soils status and fertilization: The soil of the field was sandy-loam with moderate fertility and $\mathrm{pH} 8.0$, indicating slightly alkaline nature of the soil. Based on soil analysis, the soil of the experimental field was low in nitrogen, medium in organic carbon $(0.33 \%)$, available phosphorus $(8 \mathrm{~kg} / \mathrm{ha})$ and rich in potassium $(480 \mathrm{~kg} /$ ha). Well-decomposed two years old farmyard manure was incorporated into the soil @ 10 t/ha at the time of field preparation. The field was prepared up to fine tilth by giving repeated ploughings with disc harrow followed by planking.

Crop husbandry: For raising a healthy fennel crop, 50 $\mathrm{kg}$ nitrogen, $25 \mathrm{~kg}$ phosphorus and $25 \mathrm{~kg}$ potash fertilizers were applied per hectare at the time of last ploughing. The crop was raised on one acre of land under field conditions at Research Farm of the Department of Vegetable Sciences, CCS Haryana Agricultural University, Hisar. The crop was raised by following the practices recommended in Package of Practices of CCS Haryana Agricultural University, Hisar. The crop had flowering period from 5 March to 15 April 2013.

Diversity of insect visitors/pollinators: Insect visitors/ pollinators of fennel flowers were collected by using a cone type hand net with $30 \mathrm{~cm}$ ring diameter. For this, the sweeps were made throughout flowering periods of the crop at different hours of the day after 10 per cent flowering in the crops. The crop had flowering period from 5 March to 15 April 2013. All collected insects were killed and preserved as dry specimen and were got them identified.

Abundance of insect visitors/pollinators on fennel flowers: Abundance of major insect visitors/ pollinators on fennel flowers was recorded during blooming period of the crop. The crops had their flowering time from 5 March to 15 April 2013. The counts of insect visitors were made on flowers of fennel crop per square meter area for five minutes using hand tally counter between different day hours. These observations were recorded from 7:00 a.m. to 7:00 p.m. at an interval of two hours after the initiation of 10 per cent flowering in the crop, at peak flowering and before the cessation of flowering in the crop.

Working behaviour of the insect visitors/pollinators: Individual of different insect visitor species was observed for their working behaviour, i.e., whether they were working from top or side of the flower. The movement of insect from one flower to another on umbels was also observed.

Different aspects of foraging behaviour of insect pollinators of seed spice crops were recorded as follows viz., initiation, peak activity and cessation time of different bee species were recorded. Observations on the insect pollinator's body contacts with anthers and/or stigma, whether working from top of the flower (top workers: the bees that stand on the anthers or receptacle and push their tongue and frontal parts of their body towards nectarines and touch the stigma and/or anthers) or side (side worker: the bees that push their tongue for obtaining nectar between the stamen filaments having gap while standing on petals with meso- and meta-thoracic legs) were also recorded. Ten individuals of each bee species were observed. The observations were recorded throughout the flowering period of fennel crop. Initiation and cessation time of activity of insect pollinators were also noted.

Determination of the foraging speed of insect pollinators: Foraging speed of bees was recorded in terms of time (seconds) spent by them on each flower (Free, 1993). Ten bees of each species were observed for recording time spent by them per flower at peak flowering period of the crop. The time spent to inject the proboscis and suck up the nectar or brushing/collecting pollens was considered as the time spent per flower, which was recorded with the help of a chronometer having an accuracy of 0.01 seconds. Ten observations were recorded for each bee species upto ten days in different hours of the day from 7:00 a.m. to 7:00 p.m. at an interval of two hours after the initiation of 10 per cent flowering in the crop, at peak flowering and before the cessation of flowering in the crop.

Determination of the foraging rate of insect pollinators: Foraging rate of bees was recorded in terms of the number of flowers visited per minute (Free, 1993). Ten bees of each species were observed for recording the number of flowers visited per minute at peak activity time of particular species at peak flowering period of the crop. The number of flowers visited per minute was recorded including the flying time from one flower to another flower. Ten observations were recorded for each bee species upto ten days in different hours of the day from 7:00 a.m. to 7:00 p.m. at an interval of two hours after the initiation of 10 per cent flowering in the crop, at peak flowering and before the cessation of flowering in the crop.

Counting of loose pollen grains sticking to the bee body: The loose pollen grains sticking to the body of different bee species were counted by capturing the bees gently by forceps to avoid shaking of its body on the flowers and their hind legs were amputated following the method given by Kumar (1990). The bees were captured at the time of their peak activity during peak flowering period of crop and were preserved in 70 per cent alcohol in glass vials after amputating the hind pair of legs very gently. The bees were shaken vigorously to wash out the pollen grains from their body and the rinsate containing pollen grains in $2 \mathrm{ml}$ alcohol. The number of pollens in each sample was 
counted in a haemocytometer using microscope. An aliquot of $1 \mu \mathrm{l}$ of each sample was charged on WBC counting chamber of the haemocytometer and the pollens grains were counted at 10x15 magnification of the microscope. The total number of pollen grains in the whole rinsate was calculated using the formula:

Total number of Average no of pollen grains pollen grains per $=$ counted in WBC chamber $\times$ bee per $2 \mathrm{ml}$ of $2 \mathrm{ml} \times 10^{4}$ solution

Identification of fennel crop pollen grains in rinsate was accomplished by comparing with standard pollen slides. Ten samples for each bee species were observed for counting the number of pollen grains. For the study of pollen grains, insects were captured between 1100 and $1300 \mathrm{~h}$ of the day.

Determination of the pollination efficacy: Compara-

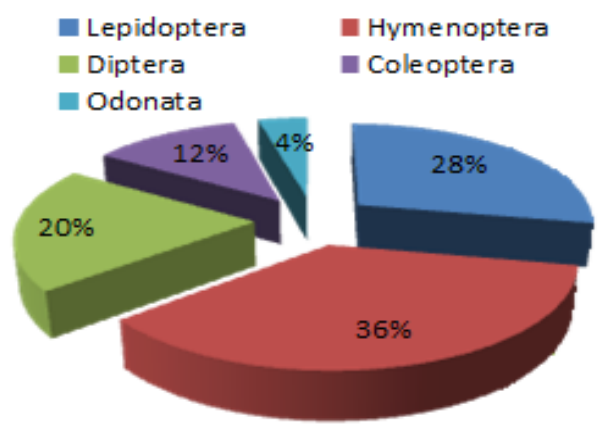

Fig. 1. Diversity of different insect pollinators in fennel flower.

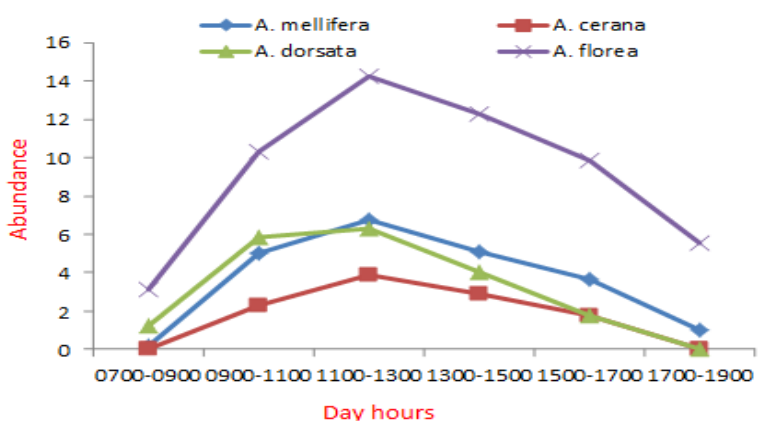

Fig. 2. Abundance of different bee species on fennel flowers at different hours of the day.

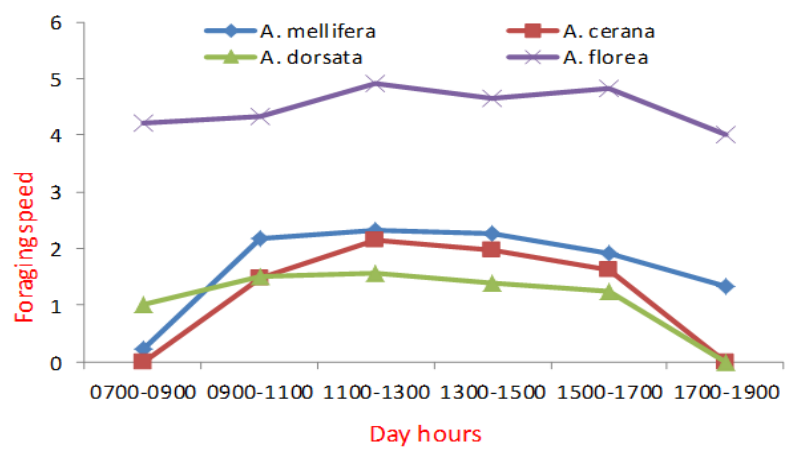

Fig. 3. Time spent by different bee species on fennel flowers at different hours of the day. tive pollination efficiency of different bee species viz., A. dorsata, A. mellifera, A. florea and A. cerana, were calculated based on their relative abundance and foraging behaviour parameters such as foraging speed, foraging rate and the number of loose pollen grains sticking to their bodies by using the formula given below:

Pollination efficacy $=$ Number of loose pollen grains $\times$ Abundance $x$ Foraging rate

Effect of abiotic factors on insect pollinators activity: To correlate the effect of different environmental factors such as temperature, relative humidity, wind velocity and rainfall was recorded by the Department of Meteorology, Chaudhary Charan Singh Haryana Agricultural University- Hisar during different hours of the day on bees' activities in fennel crop during flowering period.

Statistical analysis: The data pertaining to seed yield, test weight, and seed germination were statistically analysed by using standard analysis of variance (ANOVA) procedures.

\section{RESULTS}

Diversity of insect visitors/pollinators on fennel flowers: The data on diversity of insect visitors/pollinators on fennel cv. HF-143 flowers are presented in Table 1 and Fig. 1. Twenty five insect species belonging to fifteen families of five orders were recorded from fennel cv. HF-143 flowers, in which, seven belong to order Lepidoptera, nine to Hymenoptera, five to Diptera, three to Coleoptera and one to Odonata. Hymenopterans were the major floral visitors comprising of four families viz., Apidae (Xylocopa virginica L., Apis florea F., A. cerana indica F., A. mellifera L. and A. dorsata F.), Megachilidae (Megachile sp.), Halictidae (Halictus sp.) and Vespidae (Vespa orientalis L. and Polistes olivaceus F.). They were followed in order of diversity by dipterans from four families viz., Muscidae (Musca domestica L.), Calliphoridae (Chrysomya megacephala F.), Sarcophagidae

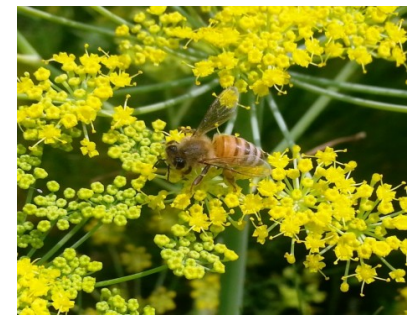

Fig. 4. A. mellifera foraging on fennel flower.

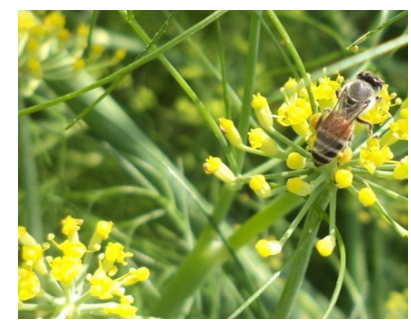

Fig. 6. A. florea foraging on fennel flower.

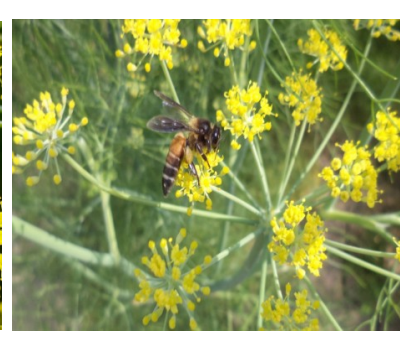

Fig. 5. A. dorsata foraging on fennel flower

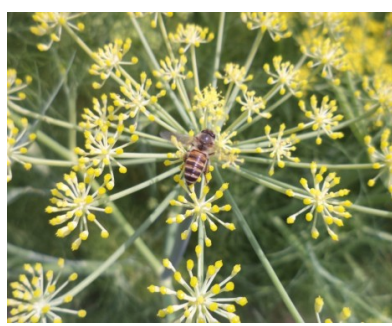

Fig. 7. A cerana foraging on fennel flower. 
Table 1. List of insect visitors/pollinators of fennel cv. HF-143 flowers.

\begin{tabular}{|c|c|c|c|c|}
\hline S. N. & Scientific name & Family & Order & Working behavior \\
\hline 1. & Danaus chrysippus L. & Nymphalidae & Lepidoptera & Top and Side \\
\hline 2. & Tirumala sp. & Nymphalidae & Lepidoptera & Top and Side \\
\hline 3. & Papilio demoleus L. & Papilionidae & Lepidoptera & Top and Side \\
\hline 4. & Pieris brassicae L. & Pieridae & Lepidoptera & Top and Side \\
\hline 5. & Terias hecabe L. & Pieridae & Lepidoptera & Top and Side \\
\hline 6. & Utethesia pulchella L. & Arctiidae & Lepidoptera & Top and Side \\
\hline 7. & Lampides boeticus L. & Lycaenidae & Lepidoptera & Top and Side \\
\hline 8. & Megachile sp. & Megachilidae & Hymenoptera & Top \\
\hline 9. & Halictus sp. & Halictidae & Hymenoptera & Top \\
\hline 10. & Xylocopa virginica $\mathrm{L}$. & Apidae & Hymenoptera & Top \\
\hline 11. & Apis florea $\mathrm{F}$. & Apidae & Hymenoptera & Top \\
\hline 12. & Apis cerana indica $\mathrm{F}$. & Apidae & Hymenoptera & Top \\
\hline 13. & Apis mellifera L. & Apidae & Hymenoptera & Top \\
\hline 14. & Apis dorsata F. & Apidae & Hymenoptera & Top \\
\hline 15. & Vespa orientalis L. & Vespidae & Hymenoptera & Top \\
\hline 16. & Polistes olivaceus F. & Vespidae & Hymenoptera & Top \\
\hline 17. & Chrysomya megacephala $\mathrm{F}$. & Calliphoridae & Diptera & Top \\
\hline 18. & Sarcophaga sp. & Sarcophagidae & Diptera & Top \\
\hline 19. & Eristalinus aeneus Scopoli & Syrphidae & Diptera & Top \\
\hline 20. & Eristalinus tabanoides Jaennicke & Syrphidae & Diptera & Top \\
\hline 21. & Musca domestica L. & Muscidae & Diptera & Top \\
\hline 22. & Coccinella septempunctata $\mathrm{L}$. & Coccinellidae & Coleoptera & Top \\
\hline 23. & Cheilomenes sexmaculata Chevrolat & Coccinellidae & Coleoptera & Top \\
\hline 24. & Brumoides suturalis $\mathrm{F}$. & Coccinellidae & Coleoptera & Top \\
\hline 25. & Ceriagrion coromandelanum $\mathrm{F}$. & Coenagrionidae & Odonata & Top and Side \\
\hline
\end{tabular}

Table 2. Abundance of different bee species on fennel cv. HF-143 flowers at different hours of the day.

\begin{tabular}{lccccccc}
\hline Bee species & \multicolumn{7}{c}{ Number of bees/ $\mathbf{m}^{2} / \mathbf{5}$ min during different day hours } \\
\cline { 2 - 7 } & $\mathbf{0 7 0 0 - 0 9 0 0}$ & $\mathbf{0 9 0 0 - 1 1 0 0}$ & $\mathbf{1 1 0 0 - 1 3 0 0}$ & $\mathbf{1 3 0 0 - 1 5 0 0}$ & $\mathbf{1 5 0 0 - 1 7 0 0}$ & $\mathbf{1 7 0 0 - 1 9 0 0}$ & Mean \\
\hline A. mellifera & $0.20(1.08)$ & $5.00(2.41)$ & $6.73(2.77)$ & $5.13(2.46)$ & $3.67(2.11)$ & $1.00(1.39)$ & $3.62(2.04)$ \\
A. cerana & $0(1.00)$ & $2.33(1.78)$ & $3.87(2.19)$ & $2.93(1.95)$ & $1.80(1.64)$ & $0(1.00)$ & $1.82(1.59)$ \\
A. dorsata & $1.27(1.46)$ & $5.87(2.57)$ & $6.33(2.69)$ & $4.00(2.20)$ & $1.80(1.64)$ & $0(1.00)$ & $3.21(1.93)$ \\
A. florea & $3.13(1.98)$ & $10.33(3.30)$ & $14.27(3.89)$ & $12.27(3.61)$ & $9.87(3.23)$ & $5.53(2.48)$ & $9.23(3.08)$ \\
Mean & $1.15(1.38)$ & $5.88(2.51)$ & $7.80(2.89)$ & $6.08(2.56)$ & $4.28(2.16)$ & $1.63(1.47)$ & \\
\hline
\end{tabular}

Each value represents mean of 15 observations at each sampling time; Figures in parentheses are $\mathrm{O}(\mathrm{x}+1)$ transformed values.

\begin{tabular}{lcc}
\hline Factors & SE(m) & C.D. $(\mathbf{p}=\mathbf{0 . 0 5})$ \\
\hline Bee species & 0.04 & 0.10 \\
Day hours & 0.04 & 0.12 \\
Bee species x Day hours & 0.09 & 0.24 \\
\hline
\end{tabular}

(Sarcophaga sp.) and Syrphidae (Eristalinus aeneus Scopoli and Eristalinus tabanoides Jaennicke), lepidopterans from five families viz., Nymphalidae (Danaus chrysippus L. and Tirumala sp.), Pieridae (Pieris brassicae L. and Terias hecabe L.), Papilionidae (Papilio demoleus L.), Lycaenidae(Lampides boeticus L.) and Arctiidae (Utethesia pulchella L.), coleopteran from one family viz., Coccinellidae (Coccinella septempunctata L., Cheilomenes sexmaculata Chevrolat and Brumoides suturalis F.) and one species from one family of order Odonata viz., Coenagrionidae (Ceriagrion coromandelanum F.). Among the insect pollinators, Apis florea, $A$. cerana indica, $A$. mellifera and $A$. dorsata were the most frequent visitors.

Abundance of insect visitors/pollinators on fennel flowers: The data on abundance statisticly analysed with two factors analysis of different honeybee species on fennel cv. HF-143 flowers at different hours of the day are presented in Table 2 and Fig. 2. Variations in abundance were recorded over time and space. Among different bee species, the maximum mean population observed in case of $A$. florea $\left(9.23 \mathrm{bees} / \mathrm{m}^{2} / 5 \mathrm{~min}\right)$ followed by $A$. mellifera (3.62 bees $\left./ \mathrm{m}^{2} / 5 \mathrm{~min}\right)$ and A. dorsata (3.21 bees $\left./ \mathrm{m}^{2} / 5 \mathrm{~min}\right)$, whereas, the least abundance was observed in case of $A$. cerana indica, i.e., $1.82 \mathrm{bees} / \mathrm{m}^{2} / 5 \mathrm{~min}$. Irrespective of different bee species, the maximum population was observed during 1100-1300 hrs of the day $\left(7.80\right.$ bees $\left./ \mathrm{m}^{2} / 5 \mathrm{~min}\right)$ followed by 1300 $1500 \mathrm{hrs}\left(6.08 \mathrm{bees} / \mathrm{m}^{2} / 5 \mathrm{~min}\right), 0900-1100 \mathrm{hrs}$ ( $5.88 \mathrm{bees} /$ $\left.\mathrm{m}^{2} / 5 \mathrm{~min}\right), 1500-1700 \mathrm{hrs}\left(4.28\right.$ bees $\left./ \mathrm{m}^{2} / 5 \mathrm{~min}\right)$ and 1700 - 
Table 3. Foraging activity of different bee species on fennel cv. HF-143 flowers at different hours of the day.

\begin{tabular}{lccc}
\hline Bee species & \multicolumn{3}{c}{ Activity time (h) } \\
\cline { 2 - 4 } & Initiation & Peak & Cessation \\
\hline A. mellifera & $0830(1)$ & $1100-1300(9)$ & $1810(2)$ \\
A. cerana & $0915(5)$ & $1100-1300(6)$ & $1630(1)$ \\
A. dorsata & $0805(3)$ & $1100-1300(9)$ & $1630(2)$ \\
A. florea & $0800(5)$ & $1100-1300(18)$ & $1820(1)$ \\
\hline
\end{tabular}

Figures in parentheses are the number of bees observed at respective time

$1900 \mathrm{hrs}\left(1.63 \mathrm{bees} / \mathrm{m}^{2} / 5 \mathrm{~min}\right)$. The lowest population was recorded during 0700-0900 hrs, i.e., 1.15 bees $/ \mathrm{m}^{2} / 5$ $\mathrm{min}$. The mean bee species population over different day hours on fennel flowers ranged from $1.82 \mathrm{bees} / \mathrm{m}^{2} / 5 \mathrm{~min}$ in case of $A$. cerana to 9.23 bees $/ \mathrm{m}^{2} / 5 \mathrm{~min}$ in case of A. florea. For $A$. florea, the maximum bee population was observed at $1100-1300 \mathrm{hrs}\left(14.27 \mathrm{bees} / \mathrm{m}^{2} / 5 \mathrm{~min}\right)$, followed by $1300-1500 \mathrm{hrs}\left(12.27 \mathrm{bees} / \mathrm{m}^{2} / 5 \mathrm{~min}\right)$ and $0900-1100 \mathrm{hrs}$ (10.33 bees $\left./ \mathrm{m}^{2} / 5 \mathrm{~min}\right)$. The least population of $A$. florea was observed during 0700-0900 hrs, i.e., $3.13 \mathrm{bees} / \mathrm{m}^{2} / 5 \mathrm{~min}$. For $A$. mellifera, the maximum bee population was observed at $1100-1300 \mathrm{hrs}(6.73 \mathrm{bees} /$ $\left.\mathrm{m}^{2} / 5 \mathrm{~min}\right)$, followed by $1300-1500 \mathrm{hrs}\left(5.13 \mathrm{bees} / \mathrm{m}^{2} / 5\right.$ min) and $0900-1100 \mathrm{hrs}\left(5.00 \mathrm{bees} / \mathrm{m}^{2} / 5 \mathrm{~min}\right)$. The least population of $A$. mellifera was observed during 0700$0900 \mathrm{hrs}$, i.e., $0.20 \mathrm{bees} / \mathrm{m}^{2} / 5 \mathrm{~min}$. For $A$. cerana, the maximum bee population was observed at 1100-1300 hrs (3.87 bees $\left./ \mathrm{m}^{2} / 5 \mathrm{~min}\right)$, followed by $1300-1500 \mathrm{hrs}(2.93$ bees $/ \mathrm{m}^{2} / 5 \mathrm{~min}$ ) and 0900-1100 hrs (2.33 bees $\left./ \mathrm{m}^{2} / 5 \mathrm{~min}\right)$. No population of $A$. cerana was observed during 0700 0900 and 1700-1900 hrs of the day. For A. dorsata, the maximum bee population was observed at $1100-1300 \mathrm{hrs}$ (6.33 bees $/ \mathrm{m}^{2} / 5 \mathrm{~min}$ ), followed by $0900-1100 \mathrm{hrs}(5.87$ bees $/ \mathrm{m}^{2} / 5 \mathrm{~min}$ ) and $1300-1500 \mathrm{hrs}$ (4.00 bees $\left./ \mathrm{m}^{2} / 5 \mathrm{~min}\right)$. No population of $A$. dorsata was observed during 1700 $1900 \mathrm{hrs}$ of the day. The cumulative mean abundance of important bee species revealed that $A$. florea was the most abundant visitor with a mean population of 9.23 bees/ $\mathrm{m}^{2} / 5$ min followed by $A$. mellifera ( 3.62 bees $/ \mathrm{m}^{2} / 5 \mathrm{~min}$ ), A. dorsata (3.21 bees $/ \mathrm{m}^{2} / 5 \mathrm{~min}$ ) and A. cerana was least frequent $\left(1.82 \mathrm{bees} / \mathrm{m}^{2} / 5 \mathrm{~min}\right)$ visitor of fennel flowers in the present investigations.

Foraging activity: The foraging activity of different bee species on fennel flowers is presented in Table 3 and Fig. 4,5,6 and 7. From the visual observations, it was observed that all the four Apis species viz., A. florea, A. mellifera, A. dorsata and A. cerana, were found to be top workers while foraging on fennel flowers. A. florea initiated foraging activity little earlier in the morning and ceased its activity little later in the evening when compared with A. cerana, A. mellifera and A. dorsata.

Results presented in Table 3 depict that $A$. florea started

Table 4. Time spent by different bee species on fennel cv. HF-143 flowers at different hours of the day.

\begin{tabular}{llllllll}
\hline Bee species & \multicolumn{7}{c}{ Time spent (sec)/ umbelet } \\
\cline { 2 - 8 } & $\mathbf{0 7 0 0 - 0 9 0 0}$ & $\mathbf{0 9 0 0 - 1 1 0 0}$ & $\mathbf{1 1 0 0 - 1 3 0 0}$ & $\mathbf{1 3 0 0 - 1 5 0 0}$ & $\mathbf{1 5 0 0 - 1 7 0 0}$ & $\mathbf{1 7 0 0 - 1 9 0 0}$ & Mean \\
\hline A. mellifera & $0.23(1.08)$ & $2.19(1.77)$ & $2.31(1.82)$ & $2.27(1.81)$ & $1.90(1.67)$ & $1.33(1.48)$ & $1.71(1.60)$ \\
A. cerana & $0(1.00)$ & $1.48(1.53)$ & $2.16(1.78)$ & $1.97(1.70)$ & $1.63(1.59)$ & $0(1.00)$ & $1.21(1.43)$ \\
A. dorsata & $1.01(1.37)$ & $1.50(1.57)$ & $1.56(1.60)$ & $1.38(1.53)$ & $1.23(1.47)$ & $0(1.00)$ & $1.11(1.42)$ \\
A. florea & $4.21(2.24)$ & $4.34(2.27)$ & $4.92(2.43)$ & $4.64(2.37)$ & $4.83(2.41)$ & $4.01(2.16)$ & $4.49(2.31)$ \\
Mean & $1.36(1.42)$ & $2.38(1.78)$ & $2.74(1.91)$ & $2.57(1.85)$ & $2.40(1.79)$ & $1.34(1.41)$ & \\
\hline
\end{tabular}

Each value represents mean of 10 observations at each sampling time; Figures in parentheses are Ö $(x+1)$ transformed values.

\begin{tabular}{lcc}
\hline Factors & SE(m) & C.D. $(\mathbf{p}=\mathbf{0 . 0 5})$ \\
\hline Bee species & 0.03 & 0.09 \\
Day hours & 0.04 & 0.11 \\
Bee species x Day hours & 0.08 & 0.23 \\
\hline
\end{tabular}

Table 5. Number of flowers visited by different bee species on fennel cv. HF-143 flowers at different hours of the day.

\begin{tabular}{lccccccc}
\hline Bee species & \multicolumn{7}{c}{ Number of umbelets visited/min } \\
\cline { 2 - 8 } & $\mathbf{0 7 0 0 - 0 9 0 0}$ & $\mathbf{0 9 0 0 - 1 1 0 0}$ & $\mathbf{1 1 0 0 - 1 3 0 0}$ & $\mathbf{1 3 0 0 - 1 5 0 0}$ & $\mathbf{1 5 0 0 - 1 7 0 0}$ & $\mathbf{1 7 0 0 - 1 9 0 0}$ & Mean \\
\hline A. mellifera & $2.06(1.37)$ & $17.68(4.19)$ & $20.62(4.65)$ & $20.40(4.63)$ & $15.82(3.85)$ & $11.66(3.11)$ & $14.71(3.63)$ \\
A. cerana & $0(1.00)$ & $16.46(3.92)$ & $20.36(4.62)$ & $18.60(4.29)$ & $16.50(3.92)$ & $0(1.00)$ & $11.99(3.12)$ \\
A. dorsata & $14.96(3.28)$ & $26.36(5.05)$ & $29.68(5.54)$ & $26.78(5.09)$ & $23.84(4.64)$ & $0(1.00)$ & $20.27(4.10)$ \\
A. florea & $6.44(2.61)$ & $7.24(2.81)$ & $8.28(3.05)$ & $8.02(3.00)$ & $7.84(2.97)$ & $6.22(2.57)$ & $7.34(2.83)$ \\
Mean & $5.87(2.06)$ & $16.94(3.99)$ & $19.74(4.46)$ & $18.45(4.25)$ & $16.00(3.84)$ & $4.47(1.92)$ & \\
\hline
\end{tabular}

Each value represents mean of 10 observations at each sampling time; Figures in parentheses are $\mathrm{O}(\mathrm{x}+1)$ transformed values.

\begin{tabular}{lcc}
\hline Factors & SE $(\mathbf{m})$ & C.D. $(\mathbf{p}=\mathbf{0 . 0 5})$ \\
\hline Bee species & 0.13 & 0.38 \\
Day hours & 0.17 & 0.46 \\
Bee species x Day hours & 0.33 & 0.92 \\
\hline
\end{tabular}


Table 6. Number of loose pollen grains sticking on the body of different bee species on fennel cv. HF-143 flowers.

\begin{tabular}{lc}
\hline Bee species & $\begin{array}{l}\text { Loose pollen grains sticking on the } \\
\text { body of different bee species (Mean) }\end{array}$ \\
\hline A. mellifera & 260,000 \\
A. cerana & 256,000 \\
A. dorsata & 303,000 \\
A. florea & 205,000 \\
\hline
\end{tabular}

Each value represents mean of 10 observations.

C.D. $(p=0.05) \quad 22,624$

$\mathrm{SE}(\mathrm{m}) \quad 7,755$

collecting pollen grains from $0800 \mathrm{hrs}$ of the day, whereas, $A$. dorsata initiated its activity from $0805 \mathrm{hrs}$ followed by $A$. mellifera ( $0830 \mathrm{hrs}$ of the day). Apis cerana started its activity little later from $0915 \mathrm{hrs}$ of the day. However, all four Apis species attained their peak activity during 1100-1300 hrs of the day and $A$. dorsata as well as $A$. cerana both ceased their activity little earlier in evening, i.e., $1630 \mathrm{hrs}$ of the day followed by A. mellifera (1810 hrs of the day), whereas, A. florea ceased its activity little later, i.e., $1820 \mathrm{hrs}$ of the day.

Foraging speed of insect visitors/pollinators on fennel flowers: The data on foraging speed statisticly analysed with two factors analysis, i.e. time spent by different bee species on fennel flower, during MarchApril 2013 have been narrated in Table 4 and Fig. 3. Among different Apis species, A. florea spent maximum time (4.49 sec/umbelet) followed by $A$. mellifera (1.71 sec/umbelet) and A.cerana (1.21 sec/umbelet). The least time per umbelet was recorded in case of $A$. dorsata, i.e., 1.11 seconds. The time spent per umbelet by different bee species differed significantly. The mean foraging speed [time spent (sec)/umbelet] varied from 4.01 to 4.92 seconds in case of $A$. florea during different hours of the day, while in case of $A$. mellifera and A. cerana, it was 0.23 to 2.31 and 1.48 to 2.16 seconds, respectively and no population of $A$. cerana was observed during 0700-0900 and 1700-1900 hrs of the day, whereas, in case of $A$. dorsata, it varied from 1.01 to 1.56 seconds and no population of $A$. dorsata was observed during 1700-1900 hrs of the day. Irrespective of different bee species, the mean time spent during different day hours differed significantly. The mean time spent by four bees during 1100-1300 hour of the day (2.74 sec/umbelet) was significantly higher than the mean time spent during 0700-0900 hrs (1.36 sec/umbelet), 0900-1100 hrs (2.38 sec/umbelet), 1300-
$1500 \mathrm{hrs}$ (2.57 sec/umbelet), 1500-1700 hrs $(2.40 \mathrm{sec} /$ umbelet) and 1700-1900 hrs (1.34 sec/umbelet) of the day.

Foraging rate of insect visitors/pollinators on fennel flowers: The data on flowers visited per minute by different bee species on fennel flowers statisticly analysed with two factors analysis is given in Table 5 . The number of flowers visited by four bee species differed significantly. Among different bees, A. dorsata visited maximum number of umbelets (20.27 umbelets/min) followed by $A$. mellifera (14.71 umbelets/min) and $A$. cerana (11.99 umbelets/min). A. florea visited least number of umbellets, i.e., 7.34 umbelets/min. Irrespective of different bee species, the maximum number of umbelets was visited during 1100 $-1300 \mathrm{hrs}$ of the day (19.74 umbelets/min) followed by 1300-1500 hrs (18.45 umbelets/min), 0900-1100 hrs (16.94 umbelets/min), 1500-1700 hrs (16.00 umbelets/ min), and 0700-0900 $\mathrm{hrs}$ (5.87 umbelets/min). The least number of umbelets/minute was visited during 1700-1900 hrs of the day, i.e., 4.47 umbelets/min. The mean foraging rate (umbelet visited/minute) in case of A. dorsata varied from 14.96 to 29.68 umbelets during different hours of the day and no population of A. dorsata was observed at 0700-0900 hrs of the day. It was 2.06 to 20.62 umbelets in case of $A$. mellifera, 16.46 to 20.36 umbelets in case of $A$. cerana and no population of $A$. cerana was observed at 0700-0900 and 1700-1900 hrs of the day, whereas, 6.22 to 8.28 umbelets/min were recorded in case of $A$. florea.

Number of loose pollen grains sticking to the body of a bee: The number of loose pollen grains sticking to the body of bees while foraging on fennel flowers has been presented in Table 6 . Significant differences were found among the number of loose pollen grains sticking to the body of different foragers of four Apis species. A. dorsata: entrapped the highest number of loose pollen grains on their body (avg. 3,03,000 pollen grains) followed by $A$. mellifera (avg. 2,60,000 pollen grains) and $A$. cerana (avg. 2,56,000 pollen grains) and it was lowest in case of $A$. florea (avg. 2,05,000 pollen grains).

Pollination efficiency: The pollination efficiency of different bee species foraging on fennel flowers presented in Table 7 depict that $A$. dorsata entrapped the maximum number of pollen grains (avg. 3,03,000 pollen gains) followed by $A$. mellifera (avg. 2,60,000 pollen grains), A. cerana (avg. 2,56,000 pollen grains) and $A$. florea (avg. 2,05,000 pollen grains). The abun-

Table 7. Pollination efficiency of different bee species on fennel cv. HF-143 flowers.

\begin{tabular}{|c|c|c|c|c|c|}
\hline Bee species & $\begin{array}{l}\text { Abundance } \\
\text { (bees } / \mathbf{m}^{2} / 5 \\
\text { min) }\end{array}$ & $\begin{array}{l}\text { Foraging rate } \\
\text { (number of flow- } \\
\text { ers visited/min) }\end{array}$ & $\begin{array}{l}\text { Loose pollen } \\
\text { grains sticking on } \\
\text { the body of bees }\end{array}$ & $\begin{array}{l}\text { Pollination } r \\
\text { (abundance } x \text { foraging } \\
\text { rate } x \text { loose pollen } \\
\text { grains) }\end{array}$ & $\begin{array}{l}\text { Pollination } \\
\text { efficiency } \\
\text { (Rank) }\end{array}$ \\
\hline A. mellifera & 3.62 & 14.71 & 260,000 & 13845052 & $3^{\text {rd }}$ \\
\hline A. cerana & 1.82 & 11.99 & 256,000 & 5586381 & $4^{\text {th }}$ \\
\hline A. dorsata & 3.21 & 20.27 & 303,000 & 19715210 & $1^{\text {st }}$ \\
\hline A. florea & 9.23 & 7.34 & 205,000 & 13888381 & $2^{\text {nd }}$ \\
\hline
\end{tabular}


Table 8. Correlation coefficient between different abiotic factors and bee species population on fennel cv. HF-143.

\begin{tabular}{lccc}
\hline Bee species & BSS & Temp $^{\mathbf{r}}\left({ }^{\mathbf{0}} \mathbf{C}\right)$ & RH \\
\hline A. mellifera & $0.833^{*}$ & $0.900^{*}$ & $-0.906^{*}$ \\
A. cerana & $0.894^{*}$ & $0.881^{*}$ & $-0.964^{* *}$ \\
A. dorsata & $0.888^{*}$ & $0.970^{*}$ & $-0.939^{*}$ \\
A. florea & $0.905^{*}$ & $0.922^{*}$ & $-0.920^{*}$ \\
\hline
\end{tabular}

*Significant at $5 \%$;* at $1 \%$; BSS means bright sunshine hours; temp means temperature; $\mathrm{RH}$ means relative humidity.

dance of $A$. florea ( $\left.9.23 \mathrm{bees} / \mathrm{m}^{2} / 5 \mathrm{~min}\right)$ was highest followed by $A$. mellifera (3.62 bees $/ \mathrm{m}^{2} / 5 \mathrm{~min}$ ) and A. dorsata (3.21 bees $\left./ \mathrm{m}^{2} / 5 \mathrm{~min}\right)$, while the abundance of $A$. cerana was least $\left(1.82 \mathrm{bees} / \mathrm{m}^{2} / 5 \mathrm{~min}\right)$. The foraging rate of $A$. dorsata (20.27 umbelets/min) was highest followed by $A$. mellifera (14.71 umbelets/min) and $A$. cerana (11.99 umbelets/min) while in case of A. florea, it was least (7.34 umbelets/min). The pollination index of $A$. dorsata was highest (19715210) followed by $A$. florea (13888381), A. mellifera (13845052) and $A$. cerana (5586381). Hence, it was observed that $A$. dorsata was the most efficient pollinator followed by $A$. florea, $A$. mellifera and $A$. cerana on fennel cv. HF-143 flowers under agro-ecological conditions of Hisar (Haryana).

Effect of abiotic factors on insect pollinator activity: The effects of different abiotic factors on the activity of different bee species have been presented in Table 8. The data depicted that the activity of different bee species on fennel varied with different abiotic factors and had significantly positive correlation with bright sun shine hours (BSS) and temperature (TEMP) in different hours of the day during foraging but had negative correlation with relative humidity $(\mathrm{RH})$. When the period of bright sunshine was longer, the total bee population was also more, and the total bee population also decreased significantly with the decrease in bright sunshine hours. In Rabi season, the warmer temperature had been favourable for the activities of bees, which increased with the increase in day temperature from morning to noon and it reached to a peak at favourable temperature and decreased with decreasing temperature. The activity of bees increased with the decrease in humidity. The relative humidity in morning and evening hours remained more as compared to afternoon. Thus, the activities of bees were more in noon hours. It was observed that the effect of wind velocity on foraging of different bee species was not significant.

\section{DISCUSSION}

In the present study twenty five: insect species belonging to fifteen families of five orders were recorded from fennel flowers, in which, seven belong to order Lepidoptera, nine to Hymenoptera, five to Diptera, three to Coleoptera and one to Odonata. Chaudhary (2006) reported that the floral visitors on fennel included 39 species belonging to 20 families and 7 orders. Earlier studies indicated that $A$. florea (Sagar, 1981; Baswana, 1984) and A. mellifera were the chief floral visitors of fennel (Youngken, 1950). Hanh et al. (2014) reported that twenty-four insect species on cucumber at agro-climatic region of hisar. Among different bee species, the maximum mean population observed in case of Apis florea ( $9.23 \mathrm{bees} / \mathrm{m}^{2} / 5 \mathrm{~min}$ ) followed by A. mellifera (3.62 bees $/ \mathrm{m}^{2} / 5 \mathrm{~min}$ ) and A. dorsata (3.21 bees $/ \mathrm{m}^{2} / 5 \mathrm{~min}$ ), whereas, the least abundance was observed in case of $A$. cerana indica, i.e., $1.82 \mathrm{bees} / \mathrm{m}^{2} / 5$ min. Irrespective of different bee species, the maximum population was observed during 1100-1300 hrs of the day (7.80 bees $/ \mathrm{m}^{2} / 5 \mathrm{~min}$ ) followed by $1300-1500 \mathrm{hrs}(6.08$ bees $/ \mathrm{m}^{2} / 5 \mathrm{~min}$ ), $0900-1100 \mathrm{hrs}$ ( $\left.5.88 \mathrm{bees} / \mathrm{m}^{2} / 5 \mathrm{~min}\right), 1500$ $1700 \mathrm{hrs}\left(4.28 \mathrm{bees} / \mathrm{m}^{2} / 5 \mathrm{~min}\right)$ and $1700-1900 \mathrm{hrs}$ ( $1.63 \mathrm{bees} /$ $\left.\mathrm{m}^{2} / 5 \mathrm{~min}\right)$. The lowest population was recorded during 0700 $0900 \mathrm{hrs}$, i.e., $1.15 \mathrm{bees} / \mathrm{m}^{2} / 5 \mathrm{~min}$. : Among different Apis species, $A$. florea spent maximum time (4.49 sec/umbelet) followed by $A$. mellifera (1.71 sec/umbelet) and A.cerana (1.21 sec/umbelet). The least time per umbelet was recorded in case of A. dorsata, i.e., 1.11 seconds. Among different bees, $A$. dorsata visited maximum number of umbelets (20.27 umbelets/min) followed by $A$. mellifera (14.71 umbelets/min) and A. cerana (11.99 umbelets/ min). A. florea visited least number of umbelets/minute (7.34 umbelets/min). Mishra et al. (1988) reported that the peak foraging activity of A. mellifera, Eristalis sp. and other dipterans were observed between 1200 and $1300 \mathrm{hrs}$, whereas, A. cerana indica and syrphids were observed between 1300 and $1400 \mathrm{hrs}$ on mustard flower at Solan (Himachal Pardesh), India. Kapil and Brar (1971) observed that A. dorsata, A. florea, and $A$. cerana indica began foraging at 0700 to $1000 \mathrm{hrs}$ on rapeseed and mustard, and the peak foraging activity was recorded between 1230 and $1400 \mathrm{hrs}$ and ceased by $1700 \mathrm{~h}$. Temperature and relative humidity have inverse relationship with each other (Sihag and Abrol, 1986). At high temperature $\left(>40^{\circ} \mathrm{C}\right)$ and low humidity, the honeybees (A. mellifera) stop foraging for nectar and/or pollens and engage in water collection (Sihag, 1990). Sunshine influences the atmospheric temperature as well as the intensity of light, both of which play an important role in flying/foraging activities of honey and other bees (Lengler and Link, 1984).

\section{Conclusion}

Biodiversity of insect pollinators on fennel cv. HF-143 (Foeniculum vulgare Miller), was studied in Hisar, Haryana, India. Twenty-five insect species belonging to fifteen families of five orders were recorded from fennel flowers, in which, seven belong to order Lepidoptera, nine to Hymenoptera, five to Diptera, three to Coleoptera and one to Odonata. Among the insect pollinators, Apis florea F., A. cerana indica F., A. mellifera L. and A. dorsata F. were the most frequent visitors. It was observed that $A$. dorsata was the most efficient pollinator followed by $A$. florea, $A$. mellifera and $A$. cerana on fennel cv. HF-143 flowers under agro-ecological conditions of Hisar (Haryana). The activity of different bee species on fennel varied with different abiotic factors and had significantly positive correlation with bright sun shine hours (BSS) and tem- 
perature (TEMP) in different hours of the day during foraging but had negative correlation with relative humidity $(\mathrm{RH})$. Thus, the impact of abiotic environmental factors would decide the foraging activity of different insect pollinators.

\section{ACKNOWLEDGEMENTS}

The authors are highly thankful to the Indian Council of agricultural Research, New Delhi (India) for providing: Junior research fellowship (J.R.F.) during the course of investigation and the Professor and Head of the Department of Entomology, CCS Haryana Agricultural University, Hisar (India) for providing necessary facilities for conducting this piece of research.

\section{REFERENCES}

Baswana, K.S. (1984). Role of insect pollination on seed production in coriander and fennel. South Indian Horticulture, 32: 117-118.

Buchmann, L.S. and Nabhan, P.G. (1996). The Forgotten Pollinators. Island Press, Washington DC, USA, pp 292.

Chaudhary, O.P. (2006). Diversity, foraging behaviour of floral visitors and pollination ecology of fennel (Foeniculum vulgare Mill.). Journal of Spices and Aromatic Crops, 15(1): 34-41.

Free, J.B. (1993). Insect Pollination of Crops (2nd edn.). Academic Press, London, UK, 544 p.

Hanh, Tran.Thi.My., Sharma, S.K. and Rana, M.K. (2014). Pollination efficiency of native bee pollinators of cucumber (Cucumis sativus L.) in India. Journal of Apiculture, 29(3): 199- 205.
Kapil, R.P. and Brar, H.S. (1971). Foraging behaviour of Apis florea F. in relation to Brassica campestris var. toria. In: Proceedings XXII International Apiculture Congress, Moscow, 335p.

Kumar, S. (1990). Studies on insect pollination in ber (Ziziphus mauritiana Lamk.). M.Sc. Thesis, Haryana Agricultural University, Hisar, Haryana, India.

Lengler, S. and Link, D. (1984). Effects of insolation and solar radiation on the flight activity of some races of honeybees . Revista do centro de ciencias rurais, 14(2): 147-151.

Mishra, R.C., Kumar, J. and Gupta, J. K., 1988. The effect of mode of pollination on yield and oil potential of Brassica campestris L. Var. sarson with observations on insect pollinators. Journal of Apicultural Research, 27 (2): 186-189.

Pruthi, J.S. (1976). Spices and Condiments. National Book Trust, New Delhi, India.

Richards, A.J. (1986). Plant Breeding Systems. Chapman and Hall, New York, USA, pp. 135-188.

Sagar, P. (1981). Role of insects in crop pollination of fennel crop at Ludhiana. PAU Journal of Research, 18(4): 8892.

Sihag, R.C. and Abrol, D.P. (1986). Correlation and pathcoefficient analysis environmental factors influencing flight activity of Apis florea F. Journal of Apicultural Research, 25(4): 202-208.

Sihag, R.C. (1990). Ecology of European honeybee, Apis mellifera L in semi-arid sub-tropical climates. I. Melliferous flora and over- seasoning of the colonies. Korean Journal of Apiculture, 5(1): 31-43.

Tewari, G.N. and Singh, K. (1983). Role of pollinators in vegetable seed production. Indian Bee Journal, 45: 51.

Youngken, H.W.Jr. (1950). Drug plant gardens and apiculture. Iowa State Apiarist Report 1949, pp. 115-122. 